\title{
CROSS-COMPATIBILITY OF CULTIVATED COWPEA VARIETIES AND THEIR WILD RELATIVES: IMPLICATIONS FOR CROP IMPROVEMENT
}

\author{
Nwosu, D. J..$^{*}$ and Nwadike, C. ${ }^{2}$ \\ ${ }^{1}$ National Centre for Genetic Resources and Biotechnology (NACGRAB), North Central Zonal \\ Office, Badeggi, Niger state-Nigeria. Headquarter Address: PMB 5382, Moor Plantation, Ibadan, \\ Nigeria. \\ ${ }^{2}$ Department of Agricultural Technology, Forestry Research Institute of Nigeria -Federal College \\ ofForestry, Jos P.M.B 2019. Jos-Plateau State, Nigeria
}

${ }^{* 1}$ Corresponding author: dicksonnwosu@ gmail.com,

\begin{abstract}
Hybridization programmes that potentially exploit the variability existing in the wild germplasm of Vigna unguiculata L. Walpers could be of great potential for the future of plant breeding. Bearing this in mind, four cultivated cowpea varieties (Achi shuru, Ife Brown, Kanannado and Zebra bean) were crossed to two of their wild relatives: subsp. dekindtiana var. pubescens and subsp. unguiculata var. spontanea to ascertain the cross compatibility, reproductive potential and possible heterosis in the $F_{1}$ generations. Results showed that the cultivated varieties hybridized relatively well with their wild relatives showing pod set range of $42.9 \%$ to $52.3 \%$ in crosses with subsp. dekindtiana var. pubescens and $40.0 \%$ to $52.0 \%$ in crosses with subsp. unguiculata var. spontanea. The $F_{1}$ hybrid plants showed high heterosis in plant height, number of leaves per plant, number of flowers per plant, number of pods per plant and percentage pod set. They also produced viable seeds for $F_{2}$ generations. These results are indications of a good reproductive potential of the hybrids thus making the wild relatives, good sources of important gene pool for the improvement of the cultivated populations.
\end{abstract}

Keywords: cowpea, $\mathrm{F}_{1}$ hybrids, pubescens, heterosis, spontanea.

https://dx.doi.org/10.4314/jafs.v19i1.8

\section{INTRODUCTION}

Cowpea (Vigna unguiculata L. Walp), one of the most important pulse crops native to West Africa, belongs to the family Fabaceae. Cultivated cowpea, which is in subspecies unguiculata, is divided into five cultivar groups namely: Unguiculata, Sesquipedalis, Textilis, Biflora and Melanophthalmus (Boukar et al., 2018). The commonly cultivated cowpea belongs to cultivar group Unguiculata while members of cultivar group Textilis, characterized by long peduncles are grown in some parts of Nigeria for production of fibre. Cowpea is a diploid with $2 n=22$ and a genome size of about 620 million base pairs. Kouam et al. (2012) and Xiong et al. (2016), stated 
Journal of Agriculture and Food Sciences

Volume 19 Number 1, April 2021 pp 110-119

Nwosu, D.J. and Nwadike, C. the area of maximum diversity of land races and cultivated cowpeas to be West and Central Africa. Cowpea is called vegetable meat due to high amount of protein in grain(s) with better biological value on dry weight basis. Cowpea grains contain $23 \%$ to $32 \%$ percent protein, 1.8 per cent fat and 60.3 per cent carbohydrates and a rich source of minerals and vitamins (Hall et al., 2003). Besides this, cowpea forms excellent forage and gives a heavy vegetative growth that covers the ground so well that it checks soil erosion and weeds. As a leguminous crop, it fixes about 70 - $240 \mathrm{~kg}$ per ha of nitrogen per year (Usman et al., 2018). Cowpea is native to West Africa where wild and weedy forms exist in many parts of the region (Ogunkanmi et al., 2008). Cop wild relatives are used in their wild state. A number of wild cowpea species (Vigna spp.) in Africa contribute directly to food security through consumption of their tubers, fruits and seeds (Biodiversity International, 2012). Crop wild relatives (CWR) are important for maintaining genetic diversity and preventing loss of germplasm due to genetic vulnerability. Wild relatives of crop species are often sourcing of genes for disease and insect resistance, increased yield, improved product quality, earliness and wide adaptations (Khoury and Guarino, 2010). Wild forms and closely related species of cowpea, therefore, have great potential as an additional source of useful germplasm for cowpea improvement (Boukar et al., 2020). The first crossings between crop wild relatives and cultivars to obtain disease resistant varieties date back to the 1890's (Biodiversity International, 2012), with pest and disease resistance currently remaining the highest priority for breeders and CWR being used primarily for this purpose.

Reports (Mohammed et al., 2010; Nwosu and Awa, 2013), have shown that wild and the weedy subspecies of cowpea ( $V$. unguiculata subsp. dekindtiana, stenophylla etc.) hybridize easily with the cultivated forms and produce viable hybrids. Mohammed et al. (2010) reported successful crossing between cultivated cowpea varieties and their wild relative (var. pubescens TVNu 110-3A). In order to utilise wild relatives of cowpea effectively for cultivar improvement, their cross compatibility and reproductive potential need be ascertained.

Members of the var. pubescens have been known to confer some degree of insect resistance on cowpea (Fatokun and Singh, 2001) owing to the presence of hairs (hence the name pubescens) on the plants. The wild cowpea variety subsp. dekindtiana var. pubescens used in this study is extremely hairy while var. spontanea is hairy. Therefore, transferring the hairiness trait from the wild lines to the cultivated varieties will be of great interest in cowpea improvement for 
Journal of Agriculture and Food Sciences

Volume 19 Number 1, April 2021 pp 110-119

Nwosu, D.J. and Nwadike, C. insect resistance and thus avoidance of pathogens transmitted by such insects. This natural occurring physiological mechanism of incompatibility in some plants enforces their out breeding and has been known to be widespread throughout the families of flowering plants (Lewis, 2008). Moreover, authors have noted the narrow genetic base of cowpea despite large number of germplasm available in gene banks (Li et al., 2001, Boukar et al, 2020). This they attributed to cowpeas high self-pollinating characteristic and consistent improvement of the crop using elite lines. The Knowledge of the genetics and physiology of self and cross incompatibility is prerequisite to planning an improvement program for a species possessing an incompatibility system (Townsend and Taylor, 2015; Muñoz-Sanz et al., 2020). The objectives of this study, therefore, were to determine the cross compatibility between four cultivated cowpea varieties and two wild cowpea relatives: subsp. dekindtiana var. pubescens and subsp. unguiculata var spontenea as well as to ascertain the viability, reproductive potential, and heterosis of the $F_{1}$ hybrids from these crosses.

\section{MATERIALS AND METHOD}

Six cowpea lines, comprising four cultivated and two wild varieties, were used in the study. The cultivated varieties are Achi shuru (landrace), Kanannado (both are cultivated widely in the Savannah region of Nigeria), Ife Brown and Zebra bean (are cultivated in the western rainforest region of Nigeria). The properties of the wild variety subsp. dekindtiana var. pubescens (collected from ATBU, Bauchi) and subsps. unguiculata var. spontenea (collected from the National Gene bank in NACGRAB, Ibadan) are described in Table 1.

The experiments were conducted in the Screen house at National Centre for Genetic Resources and Biotechnology (NACGRAB), Moor Plantation, Ibadan ( $7^{\circ} 22^{\prime} \mathrm{N}$ and $\left.3^{\circ} 50^{\prime} \mathrm{E}\right)$. The first Experiments involved hand crossing each of the four cultivated cowpea varieties to the wild varieties. This exercise was carried out between October and November 2011 as modified by Nwosu and Awa (2013). The wild varieties were used as pollen parents. Pods containing $F_{1}$ seeds were harvested at maturity. Number of flowers emasculated and pollinated and number of mature pods set were recorded and compared using percentages. Parents and $F_{1}$ seeds were sown in the second experiment at the NACGRAB Mesh House. Seeds from each of the six parents and their eight $F_{1}$ generations were sown in poly pots measuring $35 \mathrm{~cm}$ in height and $18 \mathrm{~cm}$ in 
Journal of Agriculture and Food Sciences

Volume 19 Number 1, April 2021 pp 110-119

Nwosu, D.J. and Nwadike, C. diameter. Two seeds were sown per pot and replicated five times in a completely randomized design. Seeds of the wild variety were mechanically scarified before sowing. The pots were watered regularly and weeds were hand removed. Data on mean plant height, number of leaves per plant, mean number of flowers and number of pods plant $^{-1}$ were recorded, compiled and subjected to Analysis of variance (ANOVA) using Statistics for Agricultural Systems (SAS) 9. Means with significant differences were separated using Turkey's test. Pod set was also compared using percentages.

\section{RESULTS AND DISCUSSION}

The four cultivated cowpea varieties crossed well with their wild relatives by classical breeding, producing 219 (47.81\%) mature pods out of total 458 flowers emasculated for crosses with var. pubescens and $170(46.31 \%)$ mature pods of 367 emasculated flowers for var. spontenea (Table 2). This result compares well with mean percentage pod set $(54.08 \%)$ for natural selfing of the female parents and is higher than that of the pollen parents (Table 2). Controlled crossing environment and careful handling are the likely reasons for this success. The pod set may be lowered by the pollen parents with lower pod set despite higher number of flowers (Table 2). The $\mathrm{F}_{1}$ crosses mean percentage pod set of $56.248 \%$ and $77.89 \%$ for crosses with var. pubescens and var. spontenea respectively are higher than those of the parents (Table 2), showing heterosis for pod set in the crosses and thus cross-compatibility between the cultivated cowpea and their wild relatives. The results corroborate those of Mohammed et al., 2010) and Nwosu and Awa (2013).

Viability of the $F_{1}$ seeds of all the crosses indicates good reproductive potential and is a good indication for progressive generations with improved traits. Number of flowers produced was significantly higher in the $F_{1}$ crosses as compared to the parents except for the wild genotypes (Table 2). The wild significantly produced more flowers and more pods per plant than all the other parents. However, the $F_{1}$ genotypes had a higher number of pods set than all the maternal parents. Higher number of pods leads to higher number of seeds per plant resulting in higher grain yield. This may be an indication that the high yielding capability of the wild cowpea is dominant and may have been inherited by the $\mathrm{F}_{1}$ crosses. Achi shuru x spontenea produced significantly $(\mathrm{P}<0.05)$ the greatest number of pods comparable to the wild 
Journal of Agriculture and Food Sciences

Volume 19 Number 1, April 2021 pp 110-119

Nwosu, D.J. and Nwadike, C. parents while Ife brown x spontenea had a significantly highest percentage pod set (Table 2). Similarly, the $F_{1}$ crosses had higher number of pods per plant and percentage mature pods per plant than most of the parents. However, results from percentage pod set show that more of the flowers of the wild parents were wasted as compared to the paternal parents and the $F_{1}$ crosses. Zebra bean $\mathrm{x}$ pubescens plants were significantly $(\mathrm{P}<0.05)$ taller than other genotypes while Kanannado x spontenea had significantly more leaves per plant than other genotypes (Table 3). Furthermore, plant height and number of leaves per plant were significantly higher in $F_{1}$ crosses as compared to the parents (Table 3). This result again confirms the reproductive vigour and heterosis of the $F_{1}$ crosses of cultivated cowpea and their wild relative var. pubescens over the parents. Generally, crosses with spontenea produced taller plants with more leaves, more pods and percentage pod set when compared to crosses involving pubescens. This may be an indication of good combining ability between the two subspecies.

The success of these crosses portends great potentials in the exploitation of rich gene pool of the wild to improve cultivated varieties of cowpea. This is more pertinent even now given the challenges of new diseases, pests, climate change and population explosion to food productivity and food security. Traits of resistance or tolerance to biotic and abiotic stresses could be introgressed into cowpea gene pool for improved productivity in the future.

\section{CONCLUSION}

The results show that cultivated varieties of cowpea are cross-compatible with their wild relatives; var. pubescens and var. spontenea producing viable $\mathrm{F}_{1}$ seeds with high reproductive potential as well as good hybrid vigour. It is suggested, that the gene pool of wild cowpea varieties be sourced for improvement of cultivated varieties. The further implication of this is to broaden the hitherto narrow gene pool of the cultivated cowpea. 
Journal of Agriculture and Food Sciences

Volume 19 Number 1, April 2021 pp 110-119

Nwosu, D.J. and Nwadike, C.

REFERENCES

Biodiversity International (2012). Maintaining Genetic Diversity. www.Biodiversityinternational.org. Accessed March 2012.

Boukar, O., Abberton, M., Oyatomi, O., Togola, A., Tripathi, L. And Fatokun, K. (2020). Introgression breeding in cowpea (Vigna unguiculata [L] Walp.). Frontiers in Plant Science, 11: 567425.

Boukar, O., Belko, N., Chamarthi, S., Togola, A., Batieno, J., Haruna, M., Diallo, S., et al. (2018). Cowpea (Vigna unguiculata): Genetics, genomics and breeding. 09 May 2018. https://doi.org/10.1111/pbr.12589. https://onlinelibrary. wiley.com /doi/10. 1111 /pbr.12589. Retrieved 17/02/2021.

Fatokun, C. A. and Singh, B. B. (2001). Improving cowpea-cereal systems in the dry savannah, AnnualReport, IITA, Ibadan, Nigeria, p. 79.

Hall, A.E., Cisse, N., Thiaw, S., Elawad, H.O.A., Ehlers, J.D. et al. (2003). Development of cowpea cultivars and germplasm by Bean/Cowpea CRSP. Field Crops Research, 82, 103-134.

Khoury, C. And Guarino, L. (2010). Back to the root: Wild genes for food security. www.kew.org/msbp/samara. Retrieved 12 December, 2020.

Kouam, E.B., Pasquet, R.S., Campagne, P., Tignegre, J.B., Thoen, K, Gaudin, R., et al. (2012). Genetic structure and mating system of wild cowpea populations in West Africa. BMC Plant Biology, 12, 113.

Lewis, D. (2008).Incompatibility in Flowering Plants. Published online on 21 January, 2008. https://doi.org/10.1111/j.1469-185X.1949.tb00584.x. Retrieved online on 17/02/2021

Li., C.D. Fatokun, C.A., Ubi, B., Singh, B.B. and Scoles, G.J. (2001). Determining genetic similarities and relationships among cowpea breeding lines and cultivars by microsatellite markers. Crop Science, 41, 189-197.

Mohammed, M. S., Z. Russom and Abdul, S. D. (2010). International Research Journal of Plant Science 1(5), 133.

Muñoz-Sanz, J.V., Zuriaga, E., Cruz-García, F., McClure, B. and Romero, C. (2020) Self(In) compatibility Systems: Target Traits for Crop-Production, Plant Breeding, and Biotechnology. Front Plant Science, 11:195.

Nwosu, D.J. and Awa, E.N. (2013) Cross-compatibility between some cultivated cowpea varieties and a wild relative (Subsp. dekindtiana var. pubescens). Journal of Scientific Research,5 (1), 195-200.

Ogunkanmi, L.A., Ogundipe, O.T. and Fatokun, C.A. (2008). Genetic diversity in wild relatives of cowpea (Vigna unguiculata) as revealed by simple sequence repeats (SSR) markers. Journal of Food, Agriculture and Environment, 6, 263-268.

Townsend C.E and Taylor,N.L. (2015). Incompatibility and Plant Breeding, In N.L. Taylor (Ed): Book Series: Agronomy Monographs .Chapter 14. First Published: 01 January 1985.Published Online: 26 October, 2015. Retrieved online on 17/02/2021 @ https://doi.org/10.2134/agronmonogr25.c14 
Journal of Agriculture and Food Sciences Nwosu, D.J. and Nwadike, C.

Volume 19 Number 1, April 2021 pp 110-119

Usman, B., Falusi, O., Daudu, OAY., Abubakar, A. Nwosu, D.J., Titus, S.D., and Mohammed L.M. (2018). Phenotypic variability studies in selected accessions of Nigerian wild cowpea (Vigna unguiculata L. Walp). GSE Biological and pharmaceutical Sciences, $3(1), 19-27$.

Xiong, H., Shi, A., Mou, B., Qin, J., Motes, D., Lu., W. et al. (2016). Genetic diversity and population structure of cowpea (Vigna unguiculata L. Walp). Plos One, 11(8), e0160941 
Journal of Agriculture and Food Sciences

Volume 19 Number 1, April 2021 pp 110-119

Nwosu, D.J. and Nwadike, C. APPENDICES

Table 1: Growth and physical characteristics of the four cultivated and their wild relatives used in this study.

\begin{tabular}{|c|c|c|c|c|c|c|}
\hline \multirow[b]{2}{*}{ Character } & \multicolumn{5}{|c|}{ Variety } & \multirow[b]{2}{*}{ Zebra bean } \\
\hline & $\begin{array}{c}\text { Var } \\
\text { pubescens }\end{array}$ & $\begin{array}{c}\text { Var } \\
\text { spontenea }\end{array}$ & Achishuru & Ife brown & Kanannado & \\
\hline Growth habit & Spreading & Spreading & Spreading & Semi- erect & Spreading & Spreading \\
\hline $\begin{array}{l}\text { Flower colour of } \\
\text { wing }\end{array}$ & Purple & Purple & Purple & Purple & Purple margin & Spreading \\
\hline Stem hairiness & Hairy & Hairy & Smooth & Smooth & Smooth & Smooth \\
\hline Pod shape & Straight & Straight & Straight & Straight & Coiling & Straight \\
\hline Seed coat colour & black & Coffee brown & brown & Brown & white & $\begin{array}{l}\text { Brown with } \\
\text { white stripes }\end{array}$ \\
\hline Seed size & small & small & medium & Medium & large & medium \\
\hline
\end{tabular}


Journal of Agriculture and Food Sciences

Nwosu, D.J. and Nwadike, C. Volume 19 Number 1, April 2021 pp 110-119

Table 2: Number of flowers hybridized, pod set and percentage of pod set in crosses between four cultivated cowpea and their two wild relatives.

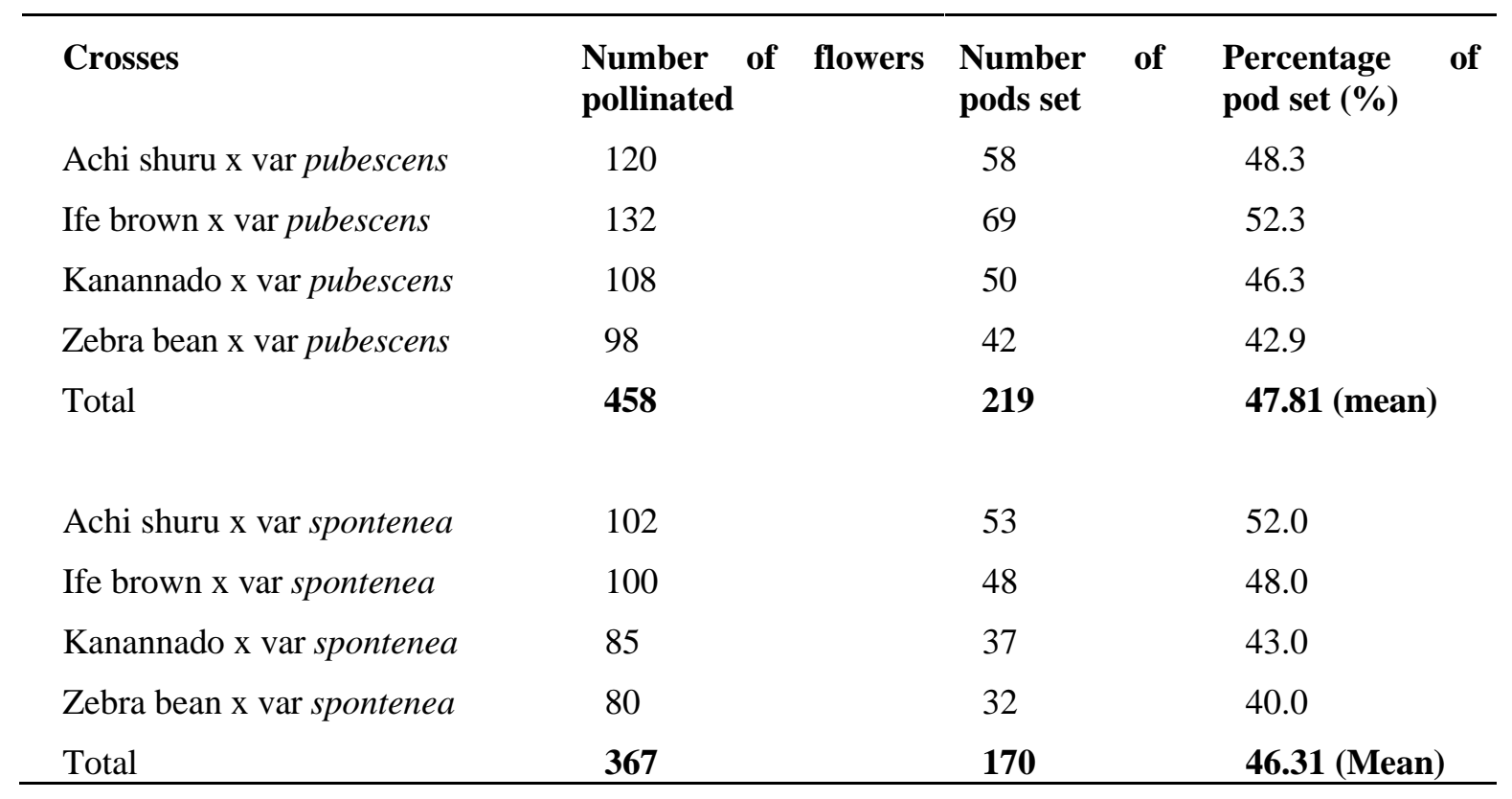


Journal of Agriculture and Food Sciences

Nwosu, D.J. and Nwadike, C.

Volume 19 Number 1, April 2021 pp 110-119

Table 3: Plant height, number of leaves, number of flowers, number of pods, percentage of mature pods produced per plant in parents and $F_{1}$ crosses of cultivated cowpea and their wild relatives.

\begin{tabular}{llllll}
\hline Treatment & Plant height & $\begin{array}{l}\text { Number of } \\
\text { leaves/plant }\end{array}$ & $\begin{array}{l}\text { Number of } \\
\text { flowers/pla } \\
\text { nt }\end{array}$ & $\begin{array}{l}\text { Number } \\
\text { of } \\
\text { pod/plant }\end{array}$ & $\begin{array}{l}\text { Percentage } \\
\text { pod set (\%) }\end{array}$ \\
\hline
\end{tabular}

\section{PARENTS}

Achi shuru

Ife Brown

Kanannado

Zebra bean

Mean

pubescens

spontenea

\section{F1 CROSSES}

\begin{tabular}{|c|c|c|c|c|c|c|}
\hline $\begin{array}{l}\text { Achi shiru } \\
\text { pubescens }\end{array}$ & $\mathrm{x}$ & $106.65^{\mathrm{bc}}$ & $25.75^{\mathrm{bcd}}$ & $58.75^{\mathrm{b}}$ & $30.25^{\mathrm{ab}}$ & $53.76^{\mathrm{c}-\mathrm{f}}$ \\
\hline $\begin{array}{l}\text { Ife Brown } \\
\text { pubescens }\end{array}$ & $\mathrm{x}$ & $92.60^{\mathrm{cd}}$ & $31.75^{\mathrm{ab}}$ & $47.00^{c}$ & $27.50^{\mathrm{bc}}$ & $58.93^{\mathrm{b}-\mathrm{e}}$ \\
\hline $\begin{array}{l}\text { Kanannado } \\
\text { pubescens }\end{array}$ & $\mathrm{x}$ & $89.05^{\mathrm{cde}}$ & $20.00^{\mathrm{d}}$ & $36.25^{\mathrm{cde}}$ & $23.75^{\text {bc }}$ & $67.81^{\mathrm{abc}}$ \\
\hline $\begin{array}{l}\text { Zebra bean } \\
\text { pubescens }\end{array}$ & $\mathrm{x}$ & $129.33^{a}$ & $32.50^{\mathrm{ab}}$ & $45.00^{c}$ & $20.00^{\mathrm{de}}$ & $44.47^{\mathrm{def}}$ \\
\hline Mean & & 104.41 & 27.50 & 46.75 & 25.38 & 56.24 \\
\hline $\begin{array}{l}\text { Achi shiru } \\
\text { spontenea }\end{array}$ & $\mathrm{x}$ & $106.85^{\mathrm{ef}}$ & $33.00^{\mathrm{ab}}$ & $44.75^{\mathrm{c}}$ & $35.00^{\mathrm{a}}$ & $79.42^{\mathrm{ab}}$ \\
\hline $\begin{array}{l}\text { Ife Brown } \\
\text { spontenea }\end{array}$ & $\mathrm{x}$ & $107.68^{\mathrm{bc}}$ & $29.25^{\mathrm{bc}}$ & $32.75^{\mathrm{de}}$ & $30.25^{\mathrm{ab}}$ & $84.62^{\mathrm{a}}$ \\
\hline $\begin{array}{l}\text { Kanannado } \\
\text { spontenea }\end{array}$ & $\mathrm{x}$ & $113.33^{\mathrm{ab}}$ & $38.00^{\mathrm{a}}$ & $40.25^{\mathrm{cd}}$ & $31.50^{\mathrm{ab}}$ & $78.31^{\mathrm{ab}}$ \\
\hline $\begin{array}{l}\text { Zebra bean } \\
\text { spontenea }\end{array}$ & $\mathrm{x}$ & $103.13^{\mathrm{bc}}$ & $32.25^{\mathrm{ab}}$ & $45.25^{\mathrm{d}}$ & $30.00^{\mathrm{ab}}$ & $69.19^{\mathrm{ab}}$ \\
\hline Mean & & 107.75 & 33.13 & 40.75 & 31.69 & 77.89 \\
\hline SEM (0.05) & & 3.70 & 1.45 & 1.07 & 1.21 & \\
\hline F- value & & 18.03 & 7.83 & 38.15 & 19.40 & \\
\hline $\mathrm{CV}$ & & 13.58 & 17.4 & 15.4 & 15.4 & \\
\hline
\end{tabular}

Means followed by the same letter(s) in the same column are not significantly different at $5 \%$ level of probability (Tukey's). 